\title{
Pengaruh Investasi dan Belanja Modal terhadap Pertumbuhan Ekonomi di Provinsi Jawa Tengah
}

\author{
Esti Winarni $^{1 *}$, Abdul Aziz Ahmad ${ }^{2}$, Suharno $^{3}$ \\ 1,2,3Fakultas Ekonomi dan Bisnis, Universitas Jenderal Soedirman \\ J1. Prof. Dr. H.R. Boenyamin No.708, Kabupaten Banyumas, 53122 \\ *Coresponding Author: azka.firza@gmail.com
}

\begin{abstract}
Abstrak. Pertumbuhan ekonomi di Provinsi Jawa Tengah adalah yang terendah jika dibandingkan dengan provinsi lain di Jawa. Penelitian ini bertujuan untuk menganalisis pengaruh penanaman modal asing, penanaman modal dalam negeri dan belanja modal terhadap pertumbuhan ekonomi di Provinsi Jawa Tengah. Penelitian ini menggunakan data sekunder dari 35 kabupaten / kota di Provinsi Jawa Tengah dengan periode 2013-2018. Metode penelitian menggunakan regresi linier berganda dengan aplikasi eviews. Hasil penelitian menunjukkan bahwa PMA dan belanja modal berpengaruh positif dan signifikan terhadap pertumbuhan ekonomi dan PMDN berpengaruh positif dan tidak signifikan terhadap pertumbuhan ekonomi di Provinsi Jawa Tengah. Implikasinya dalam penelitian ini adalah bahwa pemerintah daerah harus meningkatkan investasi dari luar negeri dan menggunakan belanja modal yang efektif dan efisien untuk mendorong pertumbuhan ekonomi.
\end{abstract}

Kata kunci: Pertumbuhan Ekonomi; Investasi Langsung Asing; Investasi Langsung Domestik; dan Belanja Modal

\begin{abstract}
Economic growth in Central Java Province is the lowest when compared to other provinces in Java. This study aims to analyze the effect of foreign direct investments, domestic direct investment and capital expenditure on economic growth in Central Java Province. This study uses secondary data from 35 regencies / cities in Central Java Province with a period of 2013-2018. The research method uses multiple line regressions with eviews application. The results showed that foreign direct investments and capital expenditure have a positive and significant effect on economic growth and domestic direct investment have a positive and not significant effect on economic growth in Central Java Province. The implication in this study is that region governments must increase investment from abroad and use capital expenditure effective and efficient in order to encourage economic growth.
\end{abstract}

Keywords: Economic Growth; Foreign Direct Investments; Domestic Direct Investment and Capital Expenditure

\section{PENDAHULUAN}

Pertumbuhan ekonomi yang tinggi merupakan harapan semua negara untuk meningkatkan kesejahteraan penduduknya. Pertumbuhan ekonomi mengukur prestasi dari perkembangan suatu perekonomian dari suatu periode ke periode berikutnya. Faktor-faktor produksi yang mengalami pertambahan dalam jumlah dan kualitasnya akan mengakibatkan meningkatnya kemampuan suatu negara untuk menghasilkan barang dan jasa dari satu periode ke periode lainnya. Dalam analisis makro, perkembangan pendapatan nasional riil yang dicapai suatu negara atau daerah dapat digunakan untuk mengukur tingkat pertumbuhan ekonomi (Sukirno, 2015). Pertumbuhan ekonomi yang di daerah diukur dengan pertumbuhan Produk Domestik Regional Bruto (PDRB). Menurut teori pertumbuhan ekonomi Neo Klasik pertumbuhan ekonmi bergantung pada perkembangan faktor-faktor produksi yang berupa modal, tenaga kerja dan teknologi (Sukirno, 2015).

Dengan adanya otonomi daerah, pembangunan daerah tetap sebagai bagian dari pembangunan nasional yang diperuntukan untuk meningkatkan kesejahteraan masyarakat. Provinsi dan kabupaten/kota sebagai daerah otonom merupakan pelaku dalam mengerakan roda perekonomian. Daerah otonom memiliki wewenang dalam serta tanggung jawab dalam menyelenggarakan kepentingan masyarakat berdasarkan prinsip-prinsip keterbukaan, partisipasi masyarakat dan pertanggungjawaban kepada masyarakat.

Pembangunan di Provinsi Jawa Tengah yang berlangsung secara menyeluruh dan berkesinambungan telah meningkatkan perekonomian masyarakat. Pencapaian hasil-hasil pembangunan belum menujukkan hasil yang memuaskan. Hal tersebut didasarkan pada pertumbuhan ekonomi di Provinsi Jawa Tengah berada di posisi terbawah jika dibandingkan dengan provinsi lainya di Pulau Jawa. Hal ini merupakan masalah yang menarik untuk dikaji mengingat letak Provinsi Jawa Tengah berada strategis di tengah Pulau Jawa serta memiliki sumber daya alam, sumber daya manusia dan prasarana penunjang yang relatif sama apabila dibandingkan dengan provinsi lain di Pulau Jawa. Fenomena tersebut dijadikan permasalahn dalam penelitian ini, sehingga perlukan dilakukan analisis lebih lanjut mengenai faktor-faktor yang memengaruhi pertumbuhan ekonomi di Provinsi Jawa Tengah. Berikut ini Tabel 1 yang menunjukkan pertumbuhan ekonomi 6 provinsi di Pulau Jawa. 
Tabel 1. PertumbuhanEkonomi 6 Provinsi di Pulau Jawa Tahun 2013-2018 (persen)

\begin{tabular}{llrrrrrrr}
\hline No & Provinsi & 2013 & 2014 & 2015 & 2016 & 2017 & 2018 & Rata \\
\hline 1 & DKI Jakarta & 6,07 & 5,91 & 5,91 & 5,87 & 6,20 & 6,17 & 6,02 \\
2 & Banten & 6,67 & 5,51 & 5,45 & 5,28 & 5,73 & 5,81 & 5,74 \\
3 & Jawa Timur & 6,08 & 5,86 & 5,44 & 5,57 & 5,46 & 5,50 & 5,65 \\
4 & Jawa Barat & 6,33 & 5,09 & 5,05 & 5,66 & 5,35 & 5,64 & 5,52 \\
5 & DI Yogyakarta & 5,47 & 5,17 & 4,95 & 5,05 & 5,26 & 6,20 & 5,41 \\
7 & Jawa Tengah & 5,11 & 5,27 & 5,47 & 5,25 & 5,26 & 5,32 & 5,28 \\
\hline
\end{tabular}

Sumber: Badan Pusat Statistik, 2018

Jika ditinjau dari teori makro ekonomi, dari pendekatan pengeluaran, pendapatan regional bruto adalah penjumlahan dari konsumsi, investasi, pengeluaran pemerintah dan ekspor netto. Investasi dari tersebut dapat bisa dari investasi luar negeri maupun dalam negeri. Investasi dalam negeri bisa berasal dari pemerintah maupun pihak swasta, investasi. investasi dari pemerintah digunakan untuk pembangunan penyedian fasilitas dan barang publik.

Pembangunan daerah memerlukan investasi yang cukup besar. Oleh karena itu, pemerintah daerah harus mampu menciptakan iklam investasi yang baik yang diukung dengan kebijakan dan infrastruktur yang memadai. Investasi dari dalam maupun luar negeri harus memiliki manfaat bagi pemerintah daerah, pihak investor, lingkungan maupun masyarakat. Semakin membaiknya iklim investasi di daerah diharapkan mampu meningkatkan pertumbuhan ekonomi, karena dengan investasi pemerintah daerah dapat memprediksi pertumbuhan dan pembangunan ekonomi. Investasi yang besar akan berdampak pada terciptanya barang modal baru, sehingga akan korelasi dengan faktor produksi baru. Dengan demikian, akan dapat menciptakan peluang kerja yang banyak dan mampu mengurangi jumlah penganguran dan kemiskinan (Todaro, 2006).

Dengan belanja modal yang dikeluarkan oleh pemerintah daerah maupun pusat secara langsung akan berdampak pada penerimaan dan pembiayaanpembiayaan daerah. Kinerja perekonomain daerah yang diukur dari pertumbuhan ekonomi akan semkin membaik apabila pengeluaran pemerintah daerah atau belanja modal digunakan untuk sektor-sektor yang bersifar produktif. Seperti halnya pembangunan sarana dan prasarana yang dialokasikan dari belanja modal daerah, secara tidak langsung akan meningkatkan intensitas kegiatan ekonomi. Dengan meningkatnya kegiatan perekonomian diharapkan mapmu meningkatkan pertumbuhan ekonomi dan akan memberikan dampak secara langsung terhadap kesejahteraan masyarakat (Putri, 2014).

Dari paparan di atas yang melatarbelakangi penelitian ini adalah pertumbuhan ekonomi di Provinsi Jawa Tengah diposisi terbawah jika dibandingkan dengan provinsi lainya di Pulau Jawa. Dengan demikian, penelitian ini bertujuan menganalisis pengaruh Penanaman Modal Asing (PMA), Penanaman Modal
Dalam Negeri (PMDN), dan belanjan modal terhadap pertumbuhan ekonomi Provinsi Jawa Tengah pada tahun 2013-2018.

\section{METODE}

Penelitian ini menggunakan pendekatan kuantitatif. Metode pengumpulan data yang digunakan dalam penelitian ini adalah metode observasi nonpartisipan, merupakan teknik pengumpulan data secara observasi dimana peneliti tidak terlibat langsung namun sebagai pengamat independen (Gujarati dan Porter, 2012). Lokasi penelitian di Provinsi Jawa Tengah dan variabel dependen dalam penelitian ini adalah pertumbuhan ekonomi serta variabel independenya adalah penanaman modal asing, penanaman modal dalam negeri, angkatan kerja, dan belanja modal. Selain itu, penelitian ini mengunakan pendekatan data penel di 35 kabupaten kota dan rentang waktu 2013 sampai dengan 2018 di Provisni Jawa Tengah. Berikut definisi operasional variabel dari penelitian ini:

1. Pertumbuhan Ekonomi menggunakan data tentang pertumbuhan Produk Domestik Regional Bruto (PDRB) kebupaten/kota di Provinsi Jawa Tengah atas dasar harga konstan, yang diukur dengan satuan persentase.

2. Penanaman Modal Asing (PMA) menggunakan data realisasi nilai penanaman modal asing (PMA) kabupaten/kota di Provinsi Jawa Tengah, yang diukur dengan satuan Dollar Amerika Serikat.

3. Penanaman Modal Dalam Negeri (PMDN) menggunakan data realisasi nilai penanaman modal dalam negeri (PMDN) kabupaten/kota di Provinsi Jawa Tengah, yang diukur dengan satuann rupiah.

4. Pengeluaran pemerintah menggunakan data realisasi belanja modal kabupaten/kota di Pemerintah Provinsi Jawa Tengah, yang diukur dengan satuan rupiah.

5. Kesempatan kerja menggunakan data jumlah penduduk produktif di kabupaten/kota Provinsi Jawa Tengah yang bekerja, yang diukur dengan satuan jiwa.

Penelitian ini menggunakan analisis data panel dimana data panel merupakan kombinasi antar data time series dan data cross section. Analisis regresi data panel adalah alat analisis regresi dimana data dikumpulkan secara individu (cross section) dan diikuti pada waktu tertentu (time series). Berikut ini persamaan yang digunakan dalam penelitian ini.

$\mathrm{PE}_{\mathrm{it}}=\beta_{0}+P M A_{i t}+\beta_{2} P M D N_{i t}+\beta_{\mathrm{a}} B M_{i t}+\beta_{4} K K_{i t}+e$

Dimana PE adalah oertumbuhan ekonomi, $\beta_{0,1,2,1,4}$ adalah koefisien regresi, PMA adalah penanaman modal asing, PMDN adalah penanaman modal dalam negeri, BM adalah belanja modal, dan KK adalak kesempaatn kerja, $e$ adalah standard error, $i$ adalah time series, $t$ adalah cross section. 
Dalam analisis data panel diperlukan penggunaan model yang tepat dalam regresi. Dalam regresi data panel terdapat tiga modal yaitu common effect, fixed effect dan random effect. Dengan demikian untuk menguji kesesuaian atau kebaikan dari tiga metode pada teknik estimasi dengan model data panel, maka digunakan Uji Lagrange Multiplier, Uji Chow dan Uji Hausman (Gujarati dan Porter, 2012). Selain itu, menurut Gujarati dan Porter (2012) model regresi yang menghasilkan estimator linear yang tidak bias yang terbaik (Best Linear Unbiased Estimator), maka perlu dilakukan pengujian untuk mengetahui model regresi yang dihasilkan memenuhi persyaratan asumsi klasik. Uji asumsi klasik yang meliputi uji normalitas, multikolinearitas, heterokedasitas, dan autokorelasi.

\section{HASIL DAN PEMBAHASAN}

Setelah melalui uji kecocokan model, penelitan ini mengunakan fixed effect model. Namun demikian, output reresi harus menyandang predikat predikat Best Linier Unbiased Estimator (BLUE) atau harus lolos uji asumsi klasik yang terdiri dari uji normalitas, multikolinearitas heteroskedastisitas, dan autokorelasi. Dalam penelitian ini output regrasi sudah dinyatakan lolos uji asumsi klasik, sehingga output output regresi ini dapat digunakan. Tabel 2 menunjukkan ringkasan output regresi dengan mengunakan fixed effect model.

Tabel 2. Ringkasan Output Regresi

\begin{tabular}{lcl}
\hline Variabel & \multicolumn{1}{c}{ Koefisien } & Probabilitas. \\
\hline Konstanta & 2,362320 & 0,0734 \\
PMDN & 0,017883 & 0,4908 \\
PMA & 0,046448 & 0,0138 \\
Belanja Modal & 1,180481 & 0,0273 \\
Adjusted R-squared & $: 0,639192$ & \\
F-statistic & $: 15,848465$ & \\
\hline
\end{tabular}

Sumber: Output regresi

Variabel PMDN memiliki koefisien regresi sebesar 0,017883 dengan nilai probabilitas sebesar 0,4908 . Hal ini menunjukkan bahwa variabel PMDN berpengaruh positif namun tidak signifikan di Provinsi Jawa Tengah. Hasil penelitian ini berbeda dengan penelitian Agustini dan Kurniasih (2017) yang menyatakan bahwa PMDN memiliki peran positif dalam meningkatkan pertumbuhan ekonomi di Provinsi Kalimantan Barat secara signifikan. Iya dan Aminu (2015) juga menemukan bahwa PMDN dan pertumbuhan ekonomi di Nigeria berhubungan positif dan signifikan. Dalam teori Harrord-Domar pembentukan modal sebagai tambahan stok modal dibutuhkan dalam menumbuhkan suatu perekonomian. Dalam menumbuhkan perekonomian tersebut diperlukan investasi-investasi baru sebagai stok penambah modal (Todaro, 2006).

Variabel PMA memiliki nilai koefisien regresi sebesar 0,046448 dengan nilai probabilitas 0,0138. Hal tersebut menunjukkan bahwa PMA memiliki pengaruh positif dan signifikan terhadap pertumbuhan ekonomi di Provinsi Jawa Tengah. temuan ini searah dengan teori pertumbuhan ekonomi aliran klasik, teori pertumbuhan ekonomi Harrod dan Domar menjelaskan bahwa kunci dalam mendorong pertumbuhan ekonomi yang tinggi adalah dengan investasi. Dengan adanya invetasi atau penenaman modal akan meningkatkan stok barang modal serta dapat meningkatkan output nasional (Rahardja dan Manurung, 2008). Hasil dari penelitian ini selaras dengan Sumadiasa, et al. (2016) yang menyimpulkan bahwa PMA berpengaruh positif dan signifikan terhadap pertumbuhan ekonomi di Provinsi Bali. Hal ini juga diperkuat dengan penelitian Tran dan Hoang (2018) yang menyatakan bahwa PMA berpengaruh positif dan signifikan terhadap pertumbuhan ekonomi di Vietnam selama periode tahun 2012-2015.

Selain itu, temuan Salebu dan Batara (2014) juga menjelaskan bahwa penanaman modal asing berpengaruh terhadap pertumbuhan ekonomi di negaranegara berkembang. Namun hal tersebut harus didukung dengan kebijakan-kabijakan pemerintah yang berorientasi pada perdagangan ke luar negeri. Zhang (2001) dan Zakaria (2009) melakukan penelitian di negara Asia Timur dan Amerika Latin menemukan terdapat hubungan kausalitas antara modal asing dengan pertumbuhan ekonomi, apabila negara-negara tuan rumah mengadopsi rezim liberalisasi perdagangan, meningkatkan pendidikan, mendorong PMA berorientasi ekspor, dan menjaga stabilitas makroekonomi.

Variabel belanja modal memiliki nilai koefisien sebesar 1,180481 dan nilai probabilitas sebesar 0,0273. Hal tersebut menunjukkan bahwa belanja modal berpengaruh positif dan signifikan terhadap pertumbuhan ekonomi di Provinsi Jawa Tengah. Pengaruh positif belanja modal terhadap pertumbuhan ekonomi sejalan dengan penelitian Waryanto (2017), Saraswati (2018), Nopiani, et al. (2016). Hasil penelitian ini sesuai dengan pendapat Prihastuti (2015) yang menjelaskan bahwa pertumbuhan ekonomi daerah dapat dipengaruhi dari pembangunan sarana dan prasarana oleh pemerintah daerah tersebut. Pembangunan sarana dan prasarana yang produktif dianggarkan melalui belanja modal yang dapat digunakan sebagai investasi daerah yang menjadi salah satu faktor pertumbuhan ekonomi. Putra dan Sulasmiyati (2016) menjelaskan belanja modal memiliki pengaruh terhadap pertumbuhan ekonomi karena pemerintah mengalokasikan anggaran belanja modal dengan efektif dan efisien dalam pembangunan infrastruktur publik untuk menunjang investasi dalam mendorong pertumbuhan ekonomi.

Selain itu, temuan Mukhlis (2012) menejlaskan bahwa belanja modal dapat berpengaruh terhadap pertumbuhan ekonomi apabila didorong dengan dengan perekonomian yang sehat, iklim investasi yang baik, stabilitas politik dan infrastruktur yang memadai. Selain itu dalam penelitianya juga menjelaskan bahwa investasi 
di sektor rill yang bergerak pada bidang industri manufaktur juga akan mempercepat dalam pertumbuhan ekonomi. Hal tersebut disebabkan aliran investasi pada sektor industri manufaktur akan lebih cepat memberikan nilai tambah pada output yang dihasilkan dan memiliki eksternalitas pisitif dalam bentuk transfer teknologi dan spillover.

\section{SIMPULAN}

Hasil penelitian menunjukan bahwa variabel penanaman modal asing dan belanja modal berpengaruh positif dan signifikan terhadap pertumbuhan ekonomi dan variabel penanaman modal dalam negeri berpengaruh positif dan tidak signifikan terhadap pertumbuhan ekonomi di Provinsi Jawa Tengah. Temuan ini mengimplikasi bahwa pemerintah daerah maupun pemerintah pusat harus meningkatkan investasi dari luar negeri dan mengunakan anggaran belanja modal dengan efektif dan efisien agar dapat mendorong pertumbuhan ekonomi.

\section{DAFTAR PUSTAKA}

Agustini, Y., \& Kurniasih, E. P. (2017). Pengaruh Investasi PMDN, PMA, dan Penyerapan Tenaga Kerja Terhadap Pertumbuhan Ekonomi dan Jumlah Penduduk Miskin Kabupaten/Kota di Provinsi Kalimantan Barat. Jurnal Ekonomi Bisnis dan Kewirausahaan (JEBIK), 6(2), 97-119 doi: 10.26418/jebik.v6i2.22986

Iya, I., \& Aminu, U. (2015). An Investigation into the Impact of Domestic Investment and Foreign Direct Investment on Economic Growth in Nigeria. International Journal of Humanities Social Sciences and Education. 2: 40-50.

Badan Pusat Statitik (2018). Badan Pusat Statistik, Jakarta.

Gujarati, D. and Porter, D, C. (2012). Basic Econometrica. Fifth Edition. New York : Mc Graw Hill.

Kuncoro, Mudrajat. 2002. Otonomi dan Pembangunan Daerah Reformasi, Perencanaan, Strategi dan Peluang. Jakarta: Airlangga.

Nopiani, N. M., Cipta, W., \& Yudiaatmaja, F. (2016). Pengaruh pendapatan asli daerah, dana alokasi umum, dan belanja modal terhadap pertumbuhan ekonomi. Jurnal Manajemen Indonesia, 4(1): 112.

Prihastuti, Taufik dan Agusti. (2015). Pengaruh Kinerja Keuangan terhadap Alokasi Belanja Modal dan Pertumbuhan Ekonomi di Kabupaten/kota Riau. Jurnal Sorot. 10(2).

Putra, M. D. K., \& Sulasmiyati, S. (2018). Pengaruh Penanaman Modal Asing dan Utang Luar Negeri terhadap Pertumbuhan Ekonomi Indonesia (Studi Pada Bank Indonesia Periode Kuartal IV 2008 2017). Jurnal Administrasi Bisnis (JAB), 58(2): 155-163.
Putri, P, I. (2014). Pengaruh Investasi, Tenaga Kerja, Belanja Modal, dan Infrastruktur Terhadap Pertumbuhan Ekonomi Pulau Jawa. JEJAK Journal of Economics and Policy, 7 (2): 100-202 doi: 10.15294jejak.v7i1.3596

Rahardja, P., dan Manurung, M. 2008. Teori Ekonomi Makro, Suatu Pengantar, Edisi Keempat. Jakarta: Lembaga Penerbit Fakultas Ekonomi Universitas Indonesia.

Salebu, S and Batara, J. (2014). The Impact of Foreign Direct Investment on Indonesian Economic Growth: Panel Data analysis For The Period 19942013, Munich Personal RePEc Archive, Paper No. 72830

Saraswati, D. (2018). Pengaruh Pendapatan Asli Daerah, Belanja Modal terhadap Pertumbuhan Ekonomi dan Dana Perimbangan sebagai Pemoderasi di Kabupaten/Kota Sumatera Utara. Jurnal Akuntansi Bisnis dan Publik, 8(2): 54-68.

Sukirno, S. (2015). Ekonomi Pembangunan Proses, Masalah, dan Dasar Kebijakan LPFE - UI, Jakarta.

Sumadiasa, I. K., Tisnawati, N. M., \& Wirathi, I. G. A. P. (2016). Analisis Pengaruh Pembangunan Infrastruktur Jalan, Listrik dan PMA terhadap Pertumbuhan PDRB Provinsi Bali Tahun 19932014. E-Jurnal Ekonomi Pembangunan Universitas Udayana, 5(7): 925-947.

Todaro, Michael P. 2006. Pembangunan Ekonomi di Dunia Ketiga, Edisi 9, Jilid 1. Jakarta: Erlangga.

Tran, H. T. T., \& Hoang, H. T. (2018). An Investigation into the Impacts of FDI, Domestic Investment Capital, Human Resources, and Trained Workers on Economic Growth in Vietnam. Studies in Computational Intelligence, 940-951. doi:10.1007/978-3-030-04200-4_69

Waryanto, P. (2017). Pengaruh Belanja Modal Terhadap Pertumbuhan Ekonomi di Indonesia. Indonesian Treasury Review: Jurnal Perbendaharaan, Keuangan Negara dan Kebijakan Publik, 2(1): 35-55. Doi: 10.33105/itrev.v2i1.13.

Zakaria, Z. (2009). Empirical evidence on the causality relationship between foreign direct investment and economic growth in the developing countries. Jurnal Ekonomi Malaysia, 43(1), 27-52.

Zhang, K. H. (2001). Does foreign direct investment promote economic growth? Evidence from East Asia and Latin America. Contemporary Economic Policy, 19(2), 175-185. 